Gut, 1975, 16, 188-192

\title{
Iron absorption in normal subjects and patients with idiopathic haemochromatosis: Relationship with serum ferritin concentration
}

\author{
G. O. WALTERS, A. JACOBS, M. WORWOOD, D. TREVETT, AND W. THOMSON \\ From the Departments of Haematology and of Medical Physics, Welsh National School of Medicine, \\ Heath Park, Cardiff
}

SUMMARY In 52 normal subjects there was an inverse relationship between serum ferritin concentration and iron absorption. In 21 measurements in 15 patients with idiopathic haemochromatosis there was a similar inverse relationship but absorption was higher in relation to iron stores at all levels. Haemochromatotic patients with normal serum ferritin levels had abnormally high values for desferrioxamine chelatable iron and there was no correlation between chelatable iron and iron absorption.

Iron balance is maintained by the regulation of iron absorption. The precise mechanism is poorly understood (Jacobs, 1973) and one of the outstanding problems is the relationship of iron stores to absorption. Heinrich (1970) has shown that in healthy subjects with haemoglobin, plasma iron, and transferrin saturation within the normal range increasing amounts of stainable iron in bone marrow particles treated by the Prussian Blue reaction are associated with a decreasing percentage absorption of iron from a test dose. The visual assessment of iron stores by this method is, at best, semiquantitative and its subjective nature gives rise to a large observer error (Bentley and Williams, 1974).

More recently, the concentration of ferritin in serum has been shown to relate closely to iron stores in normal subjects and in those with iron deficiency or overload (Jacobs, Miller, Worwood, Beamish, and Wardrop, 1972; Walters, Miller, and Worwood, 1973a; Siimes, Addiego, and Dallman, 1974). The assay of ferritin can be carried out in a reproducible manner on a small serum sample, and a preliminary study indicated an inverse relationship between serum ferritin concentration and iron absorption in normal subjects (Walters, Thompson, Jacobs, and Wood, 1973b). This assay has been used in the present study to confirm the relationship between iron stores and iron absorption in normal subjects and to compare it with data from patients with haemochromatosis.

Received for publication 17 October 1974.

\section{Subjects}

Fifty-two healthy adults (22 women and 30 men) were studied. In all cases the serum iron concentration was above $70 \mu \mathrm{g}$ per $\mathrm{dl}$ and the transferrin saturation above $16 \%$. Haemoglobin concentration was above $12.5 \mathrm{~g}$ per $\mathrm{dl}$ in women and $13.0 \mathrm{~g}$ per $\mathrm{dl}$ in men.

Fifteen patients with primary idiopathic haemochromatosis (one woman and 14 men) were studied; all met the same haematological criteria as the normal subjects. Six of the patients were studied on two occasions giving a total of 21 observations in this group. Three patients were investigated before venesection therapy, nine during and nine after the completion of a course of venesection. Patients studied during treatment were not bled for a minimum of one month before the absorption measurement.

All subjects gave their fully informed consent to the investigations.

\section{Methods}

Iron absorption was measured by whole body counting using a flat bed scanning technique. The whole body counter consists of four uncollimated $\mathrm{Nal}(\mathrm{Tl})$ crystals $10.2 \mathrm{~cm}$ thick and $15.2 \mathrm{~cm}$ in diameter arranged symmetrically on a vertical metal ring. The subject lies on a fixed bed and the detectors traverse the entire length of the bed. The detectors are connected to a multichannel analyser with 
memory size of 1024 channels. Both the detectors and the subject are inside a shielded room.

After an overnight fast the subjects consumed a standard meal of chicken soup containing approximately $2 \mathrm{mg}$ of iron and $0.5 \mu \mathrm{Ci}\left[{ }^{59} \mathrm{Fe}\right.$ ] ferric citrate. The subjects were measured in the whole body counter on three occasions: before the test meal to measure the background radioactivity, immediately after the meal, and finally 14 days later. Redistribution effects in the six hours after the test meal are negligible with the technique used here which incorporates a computer calibration devised to give the optimum energy band $(0.1 \mathrm{MeV}-0.6 \mathrm{MeV}$ for ${ }^{59} \mathrm{Fe}$ ) and the corresponding optimum end stop correction. The room background and a reference source of ${ }^{59} \mathrm{Fe}$ are counted on each occasion. The ratio of the counting rate for the ${ }^{59} \mathrm{Fe}$ in the subject to the counting rate for the ${ }^{59} \mathrm{Fe}$ reference source is evaluated for both days. The latter ratio for the 14-day measurements is expressed as a percentage of the ratio for the first day, giving the percentage iron absorption.

Blood counts were carried out using a Coulter $\mathbf{S}$ automatic cell counter; serum iron concentration and total iron-binding capacity were measured by a modified method of Young and Hicks (1965). Serum ferritin concentration was measured by the method of Addison, Beamish, Hales, Hodgkins, Jacobs, and Llewellin (1972). The differential ferrioxamine test was carried out in patients with haemochromatosis by the method of Fielding (1965).

\section{Results}

Haematological data and serum ferritin concentrations for all subjects are given in table I. Patients with haemochromatosis are divided into two groups, eight whose serum ferritin levels were within the normal range of $15-250 \mu$ ger 1 (group A) and 13 with raised levels (group B).

\section{NORMAL SUBJECTS}

Serum ferritin concentrations were within the expected range with a mean value of $75.8 \mu \mathrm{g}$ per 1 (table I). The mean value in males is $87.5 \pm 9.5 \mu \mathrm{g}$ per 1 and in females $54.8 \pm 9.7 \mu \mathrm{g}$ per 1 , a significant difference $(P<0.05)$ which agrees with previously reported results. Iron absorption ranged from 1.5 to $48 \%$ in women (mean $16.8 \%$ ) and 1.7 to $33.6 \%$ in men (mean $9.5 \%$ ). This difference is just significant $(P<0.05)$. The mean absorption for the combined group (table II) is $12.6 \%$. When all subjects are taken together (fig 1) there is a significant negative correlation between serum ferritin concentration and iron absorption $(r=-0.398, P<0.005)$. There is

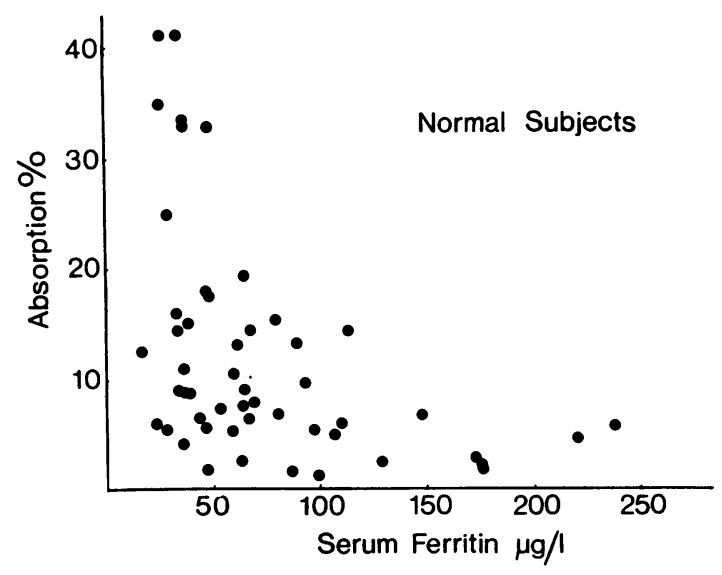

Fig 1 Serum ferritin concentration and iron absorption in normal subjects.

\begin{tabular}{|c|c|c|c|c|c|}
\hline & $\begin{array}{l}\text { Haemoglobin } \\
(\mathrm{g} / \mathrm{dl})\end{array}$ & $\begin{array}{l}\text { Serum Iron } \\
(\mu g / d l)\end{array}$ & $\begin{array}{l}\text { Transferrin } \\
\text { Saturation (\%) }\end{array}$ & $\begin{array}{l}\text { Chelatable Iron } \\
\text { (Fv) } \mu g / k g b w)\end{array}$ & $\begin{array}{l}\text { Serum Ferritin } \\
(\mu g / l)\end{array}$ \\
\hline $\begin{array}{l}\text { Normal subjects } \\
\text { Mean } \\
\text { SD } \\
\text { Range }\end{array}$ & $\begin{array}{l}14 \cdot 3 \\
1 \cdot 1 \\
12 \cdot 6-16 \cdot 8\end{array}$ & $\begin{array}{c}117 \cdot 7 \\
34 \cdot 2 \\
76-198\end{array}$ & $\begin{array}{c}31 \cdot 2 \\
8 \cdot 8 \\
17-46\end{array}$ & $\begin{array}{l}226^{2} \\
-81-404\end{array}$ & $\begin{array}{l}75 \cdot 8 \\
53 \cdot 2 \\
17-238\end{array}$ \\
\hline $\begin{array}{l}\text { Patients with haemochromatosis } \\
\text { A Mean } \\
\text { SD } \\
\text { Range }\end{array}$ & $\begin{array}{c}15 \cdot 3 \\
1 \cdot 07 \\
14 \cdot 2-17 \cdot 4\end{array}$ & $\begin{array}{c}164 \cdot 7^{8} \\
65 \cdot 2 \\
102-258\end{array}$ & $\begin{array}{l}59 \cdot 8^{4} \\
28 \cdot 0 \\
32-100\end{array}$ & $\begin{array}{l}672 \cdot 8 \\
332 \cdot 7 \\
259-1458\end{array}$ & $\begin{array}{l}97 \cdot 8 \\
46 \cdot 5 \\
58-190\end{array}$ \\
\hline $\begin{array}{l}\text { B Mean } \\
\text { SD } \\
\text { Range }\end{array}$ & $\begin{array}{l}14 \cdot 6 \\
0.95 \\
13 \cdot 0-16 \cdot 4\end{array}$ & $\begin{array}{c}245 \cdot 74 \\
54 \cdot 6 \\
136-320\end{array}$ & $\begin{array}{l}92 \cdot 54 \\
15 \cdot 2 \\
47-100\end{array}$ & $\begin{array}{l}1643 \cdot 4 \\
1149 \cdot 6 \\
361-3663\end{array}$ & $\begin{array}{l}1514.94 \\
941 \cdot 7 \\
493-3372\end{array}$ \\
\hline
\end{tabular}

Table I Iron status in normal subjects and patients with with haemochromatosis ${ }^{1}$

${ }^{\mathbf{1}} \mathbf{A}=$ patients with normal iron stores, $\mathbf{B}=$ patients with increased iron stores

smith, P. M. (1968).

Significant difference from normal ${ }^{3} P<0.01 ;{ }^{4} P<0.001$ 
no correlation between iron absorption and haemoglobin concentration, serum iron concentration, or transferrin saturation.

\section{PATIENTS WITH HAEMOCHROMATOSIS}

Serum ferritin concentrations extended through and above the normal range (table I), the highest recorded level being $3372 \mu \mathrm{g}$ per 1 . The mean iron absorption for all patients was $21.9 \%$. There was a significant negative correlation between serum ferritin concentration and iron absorption $(r=$ $-0.592, \mathrm{P}<0.01)$. Table II shows iron absorption

\begin{tabular}{|c|c|c|c|c|}
\hline & \multicolumn{4}{|c|}{ Iron Absorption ( $\%$ ) } \\
\hline & Mean & $S D$ & Range & $\begin{array}{l}\text { Difference } \\
\text { from Normal }\end{array}$ \\
\hline $\begin{array}{l}\text { Normal subjects } \\
\text { Patients with } \\
\text { haemochromatosis }\end{array}$ & $12 \cdot 6$ & $10 \cdot 9$ & $1 \cdot 5-48$ & - \\
\hline $\begin{array}{l}\text { A Normal serum ferritin } \\
\text { B High serum ferritin }\end{array}$ & $\begin{array}{l}30.0 \\
16.9\end{array}$ & $\begin{array}{l}6 \cdot 4 \\
6 \cdot 8\end{array}$ & $\begin{array}{l}20 \cdot 3-39 \\
5 \cdot 1-29 \cdot 2\end{array}$ & $\begin{array}{l}\mathrm{P}<0.001 \\
\text { ns }\end{array}$ \\
\hline
\end{tabular}

Table II Iron absorption in normal subjects and patients with haemochromatosis

in the two groups of patients, those with normal ferritin status and those with increased concentrations, separately. The mean absorption of $30.0 \%$ in patients with normal ferritin concentrations is significantly higher than the mean absorption of $12.6 \%$ in normal subjects with similar ferritin concentrations. Iron absorption in haemochromatotic patients corresponds to normal levels only when the serum ferritin concentration is significantly higher then normal. The difference between normal subjects and patients is illustrated in figure 2 .

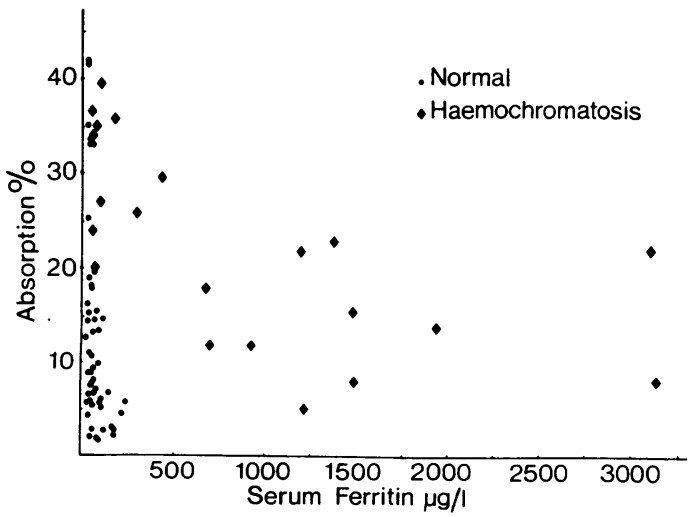

Fig 2 Serum ferritin concentration and iron absorption in normal subjects and patients with haemochromatosis.
The mean value for desferrioxamine chelatable iron (Fv) was $1227 \mu \mathrm{g}$ per kg body weight. There was a correlation between chelatable iron and serum ferritin concentration $(r=0.53, \mathrm{P}<0.02)$ though in all but one of the eight patients with a normal serum ferritin chelatable iron was above $400 \mu \mathrm{g}$ per kg body weight, the upper limit of normal. There was no significant correlation between chelatable iron and iron absorption ( $P>0.8)$. The ratio of chelatable iron to ferritin was calculated for each case and this fraction ( $\mathrm{Fv} /$ ferritin, fig 3 ) shows a positive correlation with iron absorption $(r=0.48, P<0.05)$.

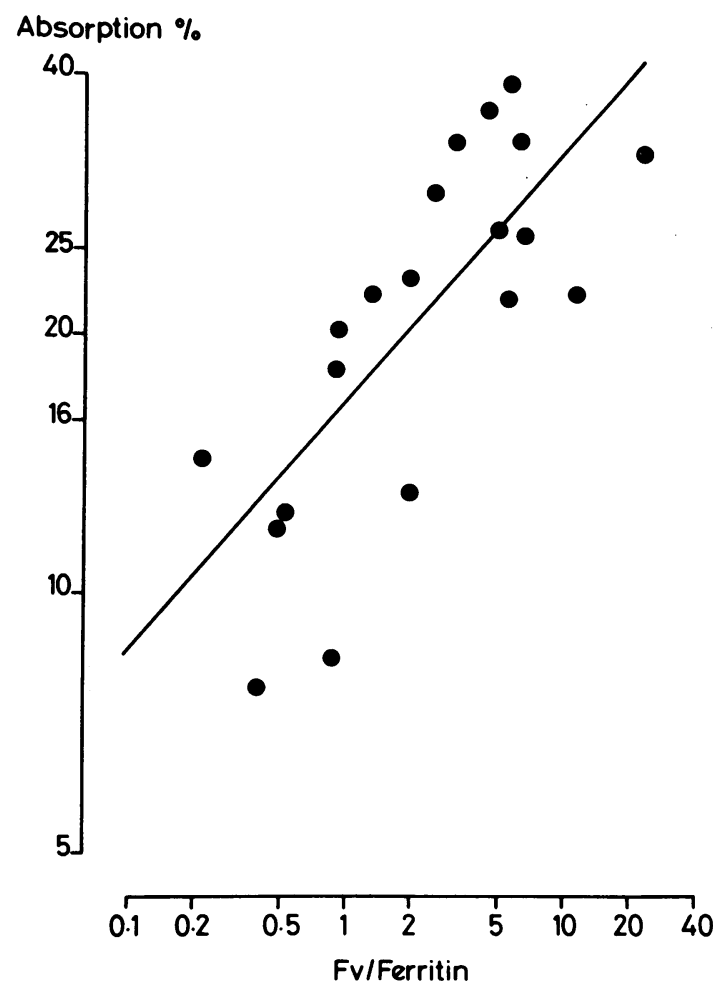

Fig 3 The ratio of chelatable iron (Fv) to ferritin and iron absorption in patients with haemochromatosis.

\section{Discussion}

The effect of venesection as such on iron absorption is relatively shortlived. Bothwell, Pizio-Biroli, and Finch (1958) showed a maximum change on the eleventh day after bleeding and Weintraub, Conrad, and Crosby (1964) showed that plasma iron levels had returned to normal by the fourteenth day. In those cases, such as that of Conrad and Crosby (1962), where venesection has led to a prolonged 
increase in iron absorption, this has been associated with depletion of iron stores. Heinrich (1970) has shown that in subjects with normal erythropoiesis and normal serum iron concentration those with no stainable iron in the bone marrow have a higher absorption of iron than those in whom reticuloendothelial deposits can be visualized by histochemical techniques. It has been known for some time that iron absorption in haemochromatosis is often normal in the fully developed state, increases after removal of the iron load, and then falls again as it reaccumulates after an interval of five to 10 years (Smith, Godfrey, and Williams, 1969).

Serum ferritin concentration has been shown to be directly proportional to the amount of storage iron mobilizable by venesection both in normal subjects (Walters et al 1973a) and in patients with idiopathic haemochromatosis (Beamish, Walker, Miller, Wormwood, Jacobs, Williams, and Corrigall, 1974). In transfusion siderosis it is related to the amount of blood administered (Jacobs et al, 1972; Letsky, Miller, Worwood, Barry, and Flynn, 1974). It normally provides a quantitative index of storage iron over a wide range, though inappropriately high serum concentrations may be found in liver disease and in certain malignancies, particularly acute leukaemia (Jones, Miller, Worwood, and Jacobs, 1973).

The present data using serum ferritin concentration as an index of storage iron confirm the previously described relationships between iron stores and iron absorption. There is a negative correlation of serum ferritin concentration with percentage absorption of an oral dose of iron both in normal subjects and in patients with haemochromatosis. In haemochromatosis mean iron absorption is higher than normal at all ferritin levels and the depression of absorption with increased iron load is associated with even higher serum ferritin levels. Calculation of the regression lines show that in normal subjects the mean absorption at a ferritin concentration of $20 \mu \mathrm{g}$ per 1 is $17.2 \%$ and at a concentration of $200 \mu \mathrm{g}$ per 1 $2.5 \%$. The corresponding absorption values in haemochromatotic patients are $27.1 \%$ and $26.0 \%$ respectively. Only in grossly iron-loaded patients (group B) with a mean serum ferritin concentration of $1539 \mu \mathrm{g}$ per 1 is the mean absorption comparable to that in normal subjects.

The mechanism by which iron stores normally influence absorption is not known. Previous attempts to demonstrate a humoral factor mediating this effect have not been successful (Conrad, 1969). Circulating ferritin appears to be a candidate for this position though preliminary experiments have not lent support to this view. Ferritin in plasma has a very rapid turnover and is destined almost entirely for uptake by liver parenchymal cells (Unger and Hershko, 1974). In rat experiments it has not been possible to influence iron absorption by the intravenous infusion of high concentrations of purified ferritin (Glover and Jacobs, unpublished observations). In haemochromatosis, although absorption is still related to circulating ferritin concentration, absorption remains inappropriately high at all levels.

The stimulation of ferritin synthesis by iron is a well recognized phenomenon (Harrison, Hoare, Hoy, and Macara, 1974) and it has been suggested (Lipschitz, Simon, Lynch, Dugard, Bothwell, and Charlton, 1971; Lynch, Lipschitz, Bothwell, and Charlton, 1974) that the immediate stimulus is enlargement of the chelatable pool. This implies a constant relationship between the size of the chelatable pool and the ferritin pool and explains why chelatable iron is usually proportional to ferritin iron stores. A previous study (Beamish et al, 1974) has shown that haemochromatotic patients with low iron stores and normal serum ferritin concentrations, either following treatment or in the process of iron accumulation, have abnormally high levels of desferrioxamine chelatable iron. The same phenomenon of increased chelatable iron associated with normal serum ferritin is seen in group A patients of the present series. The increased chelatable iron with normal ferritin levels found in patients with haemochromatosis at the beginning of their iron accumulation suggests a disturbance in their intracellular relationships with a relative decrease in ferritin synthesis (Beamish et al, 1974). The occurrence of such an imbalance in the small intestinal epithelium might well result in an inappropriately high level of iron absorption. Recent work in the field of iron absorption has provided ample evidence for the presence of a non-ferritin iron pool in intestinal cells associated with the transport of iron from the luminal to the serosal surface (Jacobs, 1973) and it has been demonstrated that iron is in a chelatable form during its transit across the small intestinal mucosa (Jacobs, Kaye, and Trevett, 1969). In normal circumstances iron taken up from the intestinal lumen is found initially in a non-ferritin fraction of the cell from which it is transferred to the plasma. Iron remaining in the non-ferritin fraction stimulates ferritin synthesis and is then sequestered in the cell as ferritin, presumably being unavailable for serosal transfer. Enlargement of the chelatable pool and impairment of ferritin synthesis would result in an increase in the amount of iron available for transferrin binding and consequently an increase in absorption.

The balance between chelatable iron and ferritin may be expressed as the ratio of the two parameters and an increase in this ratio would be expected to 
reflect an increased block in transfer of iron from the chelatable to the ferritin pool in the tissues. In the present study the fraction Fv/serum ferritin shows a positive correlation with iron absorption in haemochromatotic subjects (fig 3), lending additional strength to the suggestion that an imbalance between these two pools is related to abnormally high absorption in this condition. Additional evidence for the failure of intestinal ferritin synthesis in idiopathic haemochromatosis comes from the absence of $\mathrm{F}$ bodies, membrane-bound ferritin deposits, in the epithelial cells (Crosby, 1963). The mechanism whereby iron stores normally regulate absorption remains unclear but its sensitivity to increased stores appears to be reduced in haemochromatosis. The present data confirm the high iron absorption in haemochromatotic patients in relation to their iron load and support the view that this is associated with an imbalance between chelatable iron and ferritin synthesis. It must be assumed that the gradual accumulation of iron in haemochromatosis, together with the inability of the body to excrete more than limited amounts, results in the eventual stimulation of ferritin synthesis by an increased chelatable pool and a consequent gradual reduction of iron absorption.

\section{References}

Addison, G. M., Beamish, M. R., Hales, C. N., Hodgkins, M., Jacobs, A., and Llewellin, P. (1972). An immunoradiometric assay for ferritin in the serum of normal subjects and patients with iron deficiency and overload. J. clin. Path., 25, 326-329.

Beamish, M. R., Walker, R., Miller, F., Worwood, M., Jacobs, A., Williams, R., and Corrigall, A. (1974). Transferrin iron, chelatable iron and ferritin in idiopathic haemochromatosis. Brit. J. Haemat., 27, 219-228.

Bentley, D. P., and Williams, P. (1974). Serum ferritin concentration: as an index of storage iron in rheumatoid arthritis. J. clin. Path., 27, 786-788.

Bothwell, T. H., Pirzio-Biroli, G., and Finch, C. A. (1958). Iron absorption. I. Factors influencing absorption. J. Lab. clin. Med. 51, 24-36.

Conrad, M. E. (1969). Humoral regulation of iron absorption. Gastroenterology, 57, 225-228.
Conrad, M. E., and Crosby, W. H. (1962). The natural history of iron deficiency induced by phlebotomy. Blood, 20, 173-185.

Crosby, W. H. (1963). The control of iron balance by the intestinal mucosa. Blood, 22, 441-449.

Fielding, J. (1965). Differential ferrioxamine test for measuring chelatable iron. J. clin. Path., 18, 88-97.

Harrison, P. M., Hoare, R. J., Hoy, T. G., and Macara, I. G. (1974). Ferritin and haemosiderin: structure and function. In Iron in Biochemistry and Medicine, edited by A. Jacobs and M. Worwood. Academic Press, New York and London.

Heinrich, H. C. (1970). Intestinal iron absorption in man-methods of measurement, dose relationship, diagnostic and theraputic applications. In Iron Deficiency, edited by L. Hallberg, H. G. Harwerth, and A. Vannotti, pp. 213-296. Academic Press, New York and London.

Jacobs, A. (1973). The mechanism of iron absorption. Clin. Haemat., 2, 323-337.

Jacobs, A., Kaye, M. D., and Trevett, D. (1969). The chelation of iron during intestinal absorption. J. Lab. clin. Med., 74, 212-217.

Jacobs, A., Miller, F., Worwood, M., Beamish, M. R., and Wardrop, C. A. (1972). Ferritin in the serum of normal subjects and patients with iron deficiency and iron overload. Brit. med. J. 4, 206-208.

Jones, P. A. E., Miller, F. M., Worwood, M., and Jacobs, A. (1973) Ferritinaemia in leukaemia and Hodgkins disease. Brit. J. Cancer, 27, 212-217.

Letsky, E. A., Miller, F., Worwood, M., and Flynn, D. M. (1974). Serum ferritin in children with thalassemia regularly transfused. J. clin. Path., 27, 652-655.

Lipschitz, D. A., Simon, M. O., Lynch, S. R., Dugard, J., Bothwell, T. H., and Charlton, R. W. (1971). Some factors affecting the release of iron from reticuloendothelial cells. Brit. J. Haemat. 21, 289-303.

Lynch, S. R., Lipschitz, D. A., Bothwell, T. H., and Charlton, R. W. (1974). Iron and the reticuloendothelial system. In Iron in Biochemistry and Medicine, edited by $\mathbf{A}$. Jacobs and $\mathbf{M}$. Worwood. Academic Press, New York and London.

Siimes, M. A., Addiego, J. E., and Dallman, P. R. (1974). Ferritin in serum: diagnosis of iron deficiency and iron overload in infants and children. Blood, 43, 581-589.

Smith, P. M. (1968). Haemochromatosis factors determining iron accumulation and loss and the results of venesection therapy. MD Thesis, University of London.

Smith, P. M., Godfrey, B. E., and Williams, R. (1969). Iron absorption in idiopathic haemochromatosis and its measurement using a whole-body counter. Clin. Sci., 37, 519-53i.

Unger, A., and Hershko, C. (1974). Hepatocellular uptake of ferritin in the rat. Brit. J. Haemat., 28, 169-180.

Walters, G. O., Miller, F. M, and Worwood, M. (1973a). Serum ferritin concentration and iron stores in normal subjects. J. clin. Path., 26, 770-772.

Walters, G. O., Thompson, W., Jacobs, A., and Wood, C. S. (1973b) Iron stores and iron absorption. Lancet, 4, 1216.

Weintraub, L. R., Conrad, M. E., and Crosby, W. H. (1964). The significance of iron turnover in the control of iron absorption. Blood, 24, 19-24.

Young, D. S., and Hicks, J. M. (1965). Method for the automatic determination of serum iron. J. clin. Path., 18, 98-102. 